\title{
INTRASPECIFIC AGGRESSION: HUMANS AND HOMINIDS
}

\author{
Zoltan JOBBAGY \\ National University of Public Service, Budapest, Hungary \\ Zoltan.Jobbagy@uni-nke.hu
}

\begin{abstract}
An unwanted and long lasting consequence of the demise of the bipolar world order is the increasing number of non-state actors who constantly challenge the existing status quo. Unlike in the traditional international environment where states primarily interact with other states, the last two and a half decades witnessed states increasingly interacting with various non-state actors. These state I non-state interactions very often result in asymmetric confrontations, including asymmetric warfare. In order to better understand certain features of asymmetric warfare the author proposes a biological approach that takes advantage of recent discoveries in primate research.
\end{abstract}

\section{Keywords: intraspecific, warfare, humans, hominids, chimpanzee}

\section{Introduction}

An unwanted and long lasting consequence of the demise of the bipolar world order is the increasing number of non-state actors who constantly challenge the existing status quo. Unlike in the traditional international environment where states primarily interact with other states, the last two and a half decades witnessed states increasingly interacting with various non-state actors. The complexity of the international theatre provides these actors with an abundance of opportunities to become successful even over long periods of time.[1][2]

These state / non-state interactions very often result in asymmetric confrontations, including asymmetric warfare. An examination of the outcome of asymmetric conflicts in the last two hundred years reveals a dangerous tendency: weak actors increasingly win asymmetric conflicts. The percental outcome of strong actor / weak actor interactions that are at the heart of asymmetric conflicts dropped from 88,2 : $11,8(1800-1849)$ to $79,5: 20,5$ (1850-
$1899)$ to $55,1: 44,9(1900-1949)$ and to 45 : 55 (1950-1998).[3]

The two major wars of the 21 st century waged in Iraq and Afghanistan were, despite the technological and material advantage of the stronger, long campaigns that did not end with the defeat of the weaker. In order to better understand certain features of asymmetric warfare the author proposes a biological approach that takes advantage of recent discoveries in primate research.

\section{Persistent Illusion}

In biological terms war is an expression of intraspecific aggression for which there are countless examples in the animal kingdom. However, due to the long lasting influence of the famous Austrian etymologist Konrad Lorenz, until the early 1970s it was assumed that not much is going on in evolution in terms of intraspecific aggression. This long lasting scientific illusion, the desire to pacify biological processes is similar to other fields of 
science when it comes to war. Anthropology is a good example for this tendency.[4][5]

In his seminal book On Aggression Lorenz concluded that aggressive behaviour has the function to maintain the existence of individuals and species in two ways. First, aggression regulates the density of a species in a given habitat thus preventing the exhaustion of food resources. Second, aggression is linked to sexuality and has the function to pass on of own genes. Aggression did not have the function for him to kill other individuals belonging to the same species. Ending in certain rituals, it can make the bonds between individuals even stronger.[6]

This illusion was smashed by later research. Intraspecific aggression and death as a result of it is pretty much everyday reality for many members of a wide array of species in the animal kingdom. It became also clear that the level of intraspecific aggression in the animal kingdom very much surpasses the level of aggression found even in the most violent human societies. The only thing that limits the level of intraspecific aggression is the desire of the involved to avoid serious injuries and wounds. An injured or wounded animal may face decreasing chance to get access to food and as a result of it most serious consequences. There is no social security, no medical or health institutions in the animal kingdom. One consequence of it is that the bulk of intraspecific killing is aimed against the weaker and the defenceless. Observations prove that most such killings occur against cubs of others within the same species. Thus intraspecific aggression found in the animal kingdom is essentially asymmetric and has the function to avoid injuries and wounds.[7]

\section{Chimpanzee Encounters}

Biologically modern humans (Homo sapiens) belong to the family of Hominidae. Relatives are the chimpanzees (Pan troglodytes), the bonobos (Pan paniscus), the gorilla (Gorilla gorilla) and the orangutan (Pongo pygmaeus). The closest relative is the chimpanzee.[8]

There are three scientific discoveries that support this very close relationship. The discoveries point five million years ago when there existed a common origin of the two species. One discovery is those 4.5 million years old fossils found in Ethiopia that prove the existence of a bipedal human ancestor with a chimpanzee-like head. The second discovery is those laboratory tests that prove a strong genetic similarity between humans and chimpanzees. In fact, humans are genetically closer to chimpanzees than to gorillas. Even though recent research suggests the gap might be rather $6 \%$, the originally identified 1-2\% genetic difference might be small enough to place both species within the same genus. The third discovery is those field and laboratory observations that found striking behavioural, social and other similarities between chimpanzees and humans. Similarities in intergroup encounters of chimpanzees and human wars are among the most interesting.[8][9]

Wars of humans in all ages featured disciplined soldiers, organized warriors and coldblooded killers. Aggressive intergroup encounters of chimpanzees provide all this. Chimpanzees do hunt and eat meat. On occasion they become cannibals. It appears that chimpanzees are anything else then just funny caricatures of humans.[10]

Primitive wars of human societies and intergroup encounters of chimpanzees display remarkable similarities when it comes to dynamics. Both contain surprise attacks, the application of overwhelming force, the commitment to kill, intimidation of individuals belonging to the other group. Aggressive and violent behaviour can be observed both in chimpanzee intergroup encounters and human warfare.[11][12]

Groups of male chimpanzees conduct patrols every three to five days. They move towards the borders of their territory. Since 
chimpanzee territories overlap, this activity is very dangerous for them. Here they become silent and cautious, sniff the vegetation, climb high into the trees to observe the area of the other group. The encounter of different chimpanzee groups of similar size ends up with loud hooting, mock charges, throwing stones and sticks of various sizes. After a while the groups retreat towards the centre of their territory. However, should the encounter become asymmetric in number or situation, another scenario unfolds. In case a lone chimpanzee is located they chase it and as soon as it becomes possible, attack it ferociously. In these cases death and cannibalism can happen. Jane Goodall, one of the world's foremost experts on chimpanzees could personally observe aggression, violence and brutality that go together when encounters of chimpanzees belonging to different groups become asymmetric. In the 1970s she witnessed the unfolding intergroup dynamics of two chimpanzee groups, the Kasakela and the Kahama. In relation to what she saw she explicitly used the term warfare.[13][14]

Others too, observed similar intergroup dynamics of chimpanzees featuring warlike attributes. Toshida Nishida in Tanzania, Stella Brewer in Senegal, Christophe and Hedwig Boesch in Ivory Coast observed similar consequences of asymmetric chimpanzee encounters. Observations recorded the extinction of two entire chimpanzee groups for which another groups of chimpanzees were named.[8]

\section{Unfolding Dynamics}

Jane Goodall thinks that the behaviour of chimpanzees may be to a great extent similar to that of proto and early humans. Simple patterns of chimpanzee thinking and violence turned over millions of years into human love and hate, mercy and cruelty, harmony and - war. In military terminology chimpanzee intergroup encounters are of low intensity, irregular in appearance, and asymmetric in nature. Their attributes include the commitment to achieve numerical superiority or situational advantage with consequences of serious injuries and occasional deaths on the side of the receiving end.[13]

This very much accords with certain attributes of the primitive wars waged by humans. These wars do not involve many casualties; therefore participation is, at first glance, not very dangerous. Their level is below the military horizon of advanced societies, their dynamics is half-hearted and floppy. These wars do not require much logistic support, and there is no need for organised training and elaborate fortifications. They feature lack of discipline, command-and-control, specialisation, and principles. Primitive wars are over long time thought to be inefficient undertakings waged by volunteers and part-timers.[15][16]

Nothing is farther on in reality. The low intensity, irregular and asymmetric conflicts of the unfolding 21 st century of Iraq and Afghanistan featured attributes common with the wars of primitive humans and the intergroup encounters of chimpanzees. This form of war can have serious consequences on the lives both of individuals and groups. Since it is not waged by an institution, it penetrates into all aspects of the society involved. It destroys social structures, does not make distinctions between war and peace, soldier and civilian, enemy and criminal. It features a poisonous cocktail of subversive warfare, psychological activities, terror and counter-terror, and absolute enmity leading to genocide.[17] This form of war can be very bloody, cause the death of many, and result in serious consequences. On occasion it can come closest to the apocalyptic or absolute war Goodall observed between the Kasakela and the Kahama groups. The encounters of the two groups went until the end of 1977 when the Kahama was no more. Goodall witnessed the clear evidence of chimpanzee genocide.[18][19][8]

Observing chimpanzee intergroup 
encounters makes it possible to understand war not just as a political phenomenon spanning over some hundreds of years, a cultural phenomenon spanning over some thousands of years, or an anthropological phenomenon spanning over some tens of thousands of years. The comparison with chimpanzee intergroup encounters makes it possible to see war as a natural phenomenon spanning over millions of years.[20][21][22][8]

The significant genetic and morphological similarity between humans and chimpanzees, the evidence of aggression and violence in both species suggest that certain dynamics and attributes of war, especially when it comes to asymmetric ones, is the result of the evolutionary process. Wars waged by the Yanomamö of the Amazonas observed and recorded by Chagnon show clear similarity with the intergroup encounter of chimpanzee groups as detailed by Goodall and others. Their social setup is also similar as both form patrilinear groups ranging from some dozen to some hundreds. Raiding is the most dominant form of intergroup encounters. A small party of males deliberately intrudes into the area of the other group and as soon as asymmetric opportunity occurs they stalk to the victim, charge it brutally and kill on the spot or wound fatally. They commit nasty things that would be named as war crimes in advanced human societies.[23][16][8][24]

Long-term observations of wild chimpanzees make their intergroup aggression even more similar to wars of humans. Over a period of ten years ranging from 1999 to 2008, Mitani et. al. observed a chimpanzee group called Ngogo in Kibale National Park, Uganda. During the ten years the group killed or wounded fatally 21 chimpanzees belonging to other groups. The researchers concluded that due to the killings the Ngogo chimpanzees expanded their territory considerably, from $28,76 \mathrm{~km} 2$ to $35,16 \mathrm{~km} 2$ by annexing an area previously occupied by their neighbours.
Thus territorial expansion followed a series of lethal asymmetric attacks. The findings are consistent with the hypothesis that lethal intergroup aggression of chimpanzees can lead to territorial expansion. In this process, chimpanzees increase their access to resources that are then available to other group members, too.[25]

\section{Conclusion}

The observation of Mitani et. al. come very close to what Hobbes described as absolute war in which the meaning of right and wrong, justice and injustice becomes empty. There is no common power, no law and no injustice. Force and fraud go together with continual fear and danger of violent death. In absolute war life is solitary, poor, nasty, brutish and short.[26] Conducting raids and fighting from ambushes promote an approach that is essentially defensive. Schmitt called the approach that combines strategic defence with tactical offence telluric. It should not come as a surprise that also Clausewitz, who addressed asymmetric warfare waged by the people only shortly, did this in his book on defence.[17]

Aggression and violence are, according to Clausewitz, inherent features of war and can also be found in the intraspecific group aggression of chimpanzees living across Africa. Among chimpanzees most serious attempts at killing and the killings themselves are done when the victim can be caught helpless and relatively defenceless, and is little capable of effectively harming the attacker. These occasions of deadly fighting are asymmetrical in which casualties overwhelmingly concentrate on the receiving end. This pattern is remarkably uniform also among humans in the primitive warfare of any society of hunter-gatherers and primitive agriculturalists. It was observable regularly in the asymmetric warfare waged in various areas of operations ranging from Iraq to Afghanistan, too. Raiding chimps and insurgents fighting for non-state actors 
appear to have similar motivations. Members of both species avoid serious, deadly, face-to-face confrontations to avoid the risk to oneself and to one's close kin. Wounds gained in symmetric confrontations may be most dangerous and can reduce the chance to get to resources to sustain one's living. The life of raiding chimpanzees and of insurgents is highly insecure and fraught with violent death. For chimpanzees there is no social security in nature and wounds might mean starvation, which is also true for humans living in the unfortunate parts of the world.

\section{References}

[1] Imre Porkolab, Az irreguláris hadviselés adaptációja és müködési mechanizmusa , Honvédségi Szemle, Vol. 143, No. 3, pp. 11-17, 2015.

[2] Imre Porkolab, When the Goldfish meets the Anaconda: A modern fable on unconventional leadership, Counter Terrorism Exchange, Vol. 3, No. 3, pp. 8-12, August 2013.

[3] Ivan Arreguin-Toft, How the Weak Win Wars: A Theory of Asymmetric Conflict, International Security, Vol. 26, No. 1, Summer 2001, pp. 97-99.

[4] Lawrence H. Keeley, War Before Civilization, The Myth of the Peaceful Savage, Oxford, Oxford University Press, 1996, pp. 3-8

[5] Irenaus Eibl-Eibesfeldt, The Biology of Peace and War: Men, Animals and Aggression, New York, The Viking Press, 1979, pp. 20-35.

[6] Konrad Lorenz, On Agression, London and New York, Routledge Classics, 2002, pp. 21-45, 54-81.

[7] Azar Gat, War in Human Civilization, Oxford, Oxford University Press, 2006, pp. 3-10, 36-113, 114-132.

[8] Richard Wrangham and Dale Peterson, Demonic Males, Apes and the Origins of Human Violence, Boston and New York, Mariner Books, 1996, pp. 35-40.

[9] Gyrus, War \& the Noble Savage, Being A Critical Inquiry into Recent Accounts of Violence amongst Uncivilized Peoples, London, Dreamflesh Press, 2009, p. 35.

[10] Michael Ghiglieri, War Among the Chimps, Discover, Vol. 8, No. 11, November 1987, p. 68.

[11] Steven A. LeBlanc and Katherine E.Register, Constant Battles, The Myth of the Peaceful, Noble Savage, New York, St. Martin's Press, 2003, p. 78.

[12] Dan Jones, Killer Instincts, Nature, Vol. 451, 31 January 2008, p. 514.

[13] Jane Goodall, In the Shadow of Man, Boston, Houghton Miflin, 1988, pp. 10-11.

[14] John C. Mitani, and David P. Watts, and Martin N. Muller, Recent Developments in the Study of Wild Chimpanzee Behavior, Evolutionary Anthropology, Vol. 11, No. 1. pp. 18-21.

[15] Marvin Harris and Orna Johnson, Cultural Anthropology, Pearson Education, 2003, pp. 164-165;

[16] Robert Gardner and Karl G.Heider, Gardens of War, Life and Death in the New Guinea Stone Age, Random House, 1968, pp. 135-144.

[17] Carl, Schmitt, The Theory of the Partisan, A Commentary/Remark on the Concept of the Political, Duncker \& Humblot, 1963; angol fordítás A. C. Goodson, Michigan State University, East Lansing, 2004, pp. 6-7, 10-55, Internet, accessed 20. 11. 2014, available at: http://obinfonet.ro/docs/tpnt/tpntrex/cschmitt-theory-of-the-partisan.pdf.

[18] Martin van Creveld, The Transformation of War, The Most Radical Intepretation of Armed Conflict since Clausewitz, The Free Press, 1991., pp. 21-22 
[19] Roger Trinquier, Modern Warfare, A French View of Counterinsurgency, Praeger Security Intenational, 2006.

[20] John Keegan, A History of Warfare, Pimlico, 1994;

[21] Brian R. Ferguson and Neil L. Whitehead (eds.), War in the Tribal Zone: Expanding States and Indigenous Warfare, School for Advanced Research Press, 2002.

[22] Brian R. Ferguson, Warfare, Culture, and Environment, Academic Press, 1984.

[23] Napoleon Chagnon, Yanomamo - The Last Days Of Eden, Mariner Books, 1992, pp. 182-241.

[24] Sohaib Gabsis and Scott Shaw, Crisis in the Central African Republic: Muslim Minorities and the Descent into Sectarian Conflict, Prepared for the All-Parliamentary Group for the Prevention of Genocide and other Crimes against Humanity, Internet, accessed 05. 09. 2016, available at: http://www4.carleton.ca/cifp/app/ serve.php/1497.pdf.

[25] John C. Mitani and David P. Watts and Sylvia J. Amsler, Lethal intergroup aggression leads to territorial expansion in wild chimpanzees, Correspondences, Current Biology, Volume 20, Issue 12 (2010), pp. R507-508.

[26] Thomas Hobbes, Leviathan or the Matter, Forme, \& Power of a Common-wealth Ecclesiasticall and Civill, London, 1651, p. 78, Internet, accessed 08. 09. 2016, available at: http://socserv2.socsci.mcmaster.ca/econ/ugcm/3113/hobbes/Leviathan.pdf. 